\title{
ANALISIS FAKTOR-FAKTOR YANG MEMPENGARUHI PENDAPATAN PETANI PADI WANITA DI KECAMATAN SAMUDERA KABUPATEN ACEH UTARA
}

Umaruddin Usman $^{* a}$, Mauliza Yanti ${ }^{* b}$

*Fakultas Ekonomi dan Bisnis Universitas Malikussaleh

a Corresponding author: umaruddin@unimal.ac.id

b yantiekp@gmail.com

\section{A R T I C L E I N F O R M A T I O N A B S T RA C T}

Keywords: Capital, Land area, Experience, Production Costs, Total Production, Income
This study aims to analyze the factors affecting the income of female rice farmers in Samudera District, North Aceh Regency. The data used in this study are primary data, namely women farmers in Samudera District, amounting to 51 people. This research model uses multiple linear regression. The results of the research. Partially, capital, land area and experience affect the income of female farmers in Samudera District. Production costs have a negative effect on the income of female farmers in Samudera District. The amount of production does not affect the income of female farmers in Samudera District

\section{PENDAHULUAN}

Indonesia merupakan salah satu negara berkembang dengan sector pertanian. Pertanian di Indonesia yang meliputi tanaman pangan, tanaman perkebunan, kehutanan, dan perikanan yang diupayakan oleh masyarakat tani Indonesia yang diharapkan memenuhi kebutuhan dalam negeri bahkan dapat dijadikan untuk menjadi sumber devisa negara dengan memerlukan upaya dukungan dan perhatian dari pemerintah agar produk-produk pertanian yang diharapkan tercapai. Pertanian di Indonesia yang mencakup tanaman pangan memerlukan perhatian khusus dari pemerintah karena selain untuk meningkatkan kesejahteraan petani pangan di Indonesia, juga untuk menjaga stabilitas ekonomi di Indonesia akan ketahanan pangan dalam negeri.

Kebutuhan padi sebagai bahan makanan pokok di negara kita masih saja mengalami kenaikan. Produksi yang dihasilkan dari hasil tanaman dalam negeri masih belum memenuhi kebutuhan. Tiap tahun pemerintah harus mengimpor beras ratusan ribu ton dari luar negeri. Namun demikian bukan berarti bahwa kita tidak mempunyai usaha untuk meningkatkan hasil pertanian tersebut, justru karena itulah petani harus meningkatkan segala daya dan upaya agar produksi padi negara kita semakin melimpah dan bisa memenuhi kebutuhan masyarakat (Sugeng, 2003).
Kabupaten Aceh Utara merupakan salah satu daerah yang memiliki potensi tanaman pangan khususnya padi di Provinsi Aceh. Salah satu wilayah penghasil padi di Kabupaten Aceh Utara adalah Kecamatan Samudera. Di Kecamatan ini terdapat luas lahan pertanian padi mencapai 1.533 Ha yang terdiri dari lahan sawah irigasi teknis seluas $1.407 \mathrm{Ha}$ dan $126 \mathrm{Ha}$ dengan irigasi non teknis. Desa yang memiliki luas lahan terbesar adalah Desa Pulo dengan luas $76 \mathrm{Ha}$, Desa Kitou seluas 75 Ha, Desa Madan dan Matang Tunong masing-masing 74 Ha (BPS Aceh Utara, 2018). Sehingga penulis meneliti di keempat desa yang tersebut di atas karena memiliki luas lahan sawah paling luas dibandingkan dengan desa-desa lain di Kecamatan Samudera.

Di Kecamatan Samudera, petani dapat menanam padi 5 kali dalam dua tahun. Mata pencaharian sebagai petani padi ditekuni oleh sebagian besar masyarakat di Kecamatan ini, namun juga ada yang sebagai mata pencaharian tambahan. Meskipun petani padi lebih identik dengan pekerjaan kaum laki-laki karena membutuhkan tenaga lebih besar untuk mengolah tanah hingga panen. Namun, di Kecamatan Samudera kaum wanita hampir mampu mendominasi kaum laki-laki untuk menjadi petani. Tercatat sebanyak 397 kaum wanita terlibat aktif sebagai petani padi. Luas lahan sawah mereka setiap musim tanam mengelola lahan sawah nya 
sendiri hingga panen. Aktivitas bertani sawah oleh kaum wanita di Kecamatan Samudera dilakukan untuk menghasilkan pendapatan untuk memenuhi kebutuhan rumah tangga. Namun, dalam memperoleh pendapatan, tidak terlepas dari faktorfaktor yang mempengaruhinya seperti modal, luas lahan, pengalaman bertani, biaya produksi, jumlah produksi.

Kondisi modal, luas lahan, pengalaman bertani, biaya produksi, jumlah produksi serta pendapatan petani padi wanita di Kecamatan Samudera dapat dilihat pada Tabel 1.1 berikut:

faktor-faktor yang mempengaruhi pendapatan petani padi wanita di Kecamatan Samudera adalah faktor modal, luas lahan, pengalaman bertani, biaya produksi dan jumlah produksi.

Modal yaitu jumlah uang yang dikeluarkan petani padi untuk setiap kali musim tanam. Modal petani padi wanita di Kecamatan Samudera diperoleh dari modal sendiri dan ada juga dari modal pinjaman. Menurut teori yang dikemukakan oleh Soekartawi (2006), semakin tinggi modal maka akan meningkatkan pendapatan petani. Fenomena yang terjadi di Kecamatan Samudera Marlina yang mengeluarkan modal sebesar Rp. 2.200.000 untuk sekali musim tanam lebih besar daripada Nurma sebesar Rp. 1.700.000, namun pendapatan yang dihasilkan Marlina hanya Rp. 2.400.000 lebih rendah dari pada Nurma yang memperoleh pendapatan Rp. 3.200.000. Hal ini disebabkan modal yang dikeluarkan oleh Marlina untuk pupuk dan pestisida tidak efesien, karena Marlina tidak merawat tanaman padi nya dengan baik.

Di samping faktor modal, pendapatan petani padi wanita dipengaruhi oleh luas lahan. Dalam ilmu usahatani, semakin luas lahan yang dikuasai, maka akan semakin tinggi pula pendapatan yang dihasilkan. Menurut Soekartawi (2006), semakin luas lahan garapan yang diusahakan petani, maka akan semakin meningkat pendapatan yang diterima. Fenomena yang terjadi di lokasi penelitian adalah luas lahan Fakriah sebesar 0,60 Ha lebih luas dibandingkan lahan yang dimiliki oleh Nurma, namun pendapatan Nurma lebih tinggi meskipun hanya memiliki luas lahan 0,40 Ha. Hal ini disebabkan pola tanam yang dilakukan Fakriah masih dengan pola lama yang tidak menjamin produksi padi meningkat.

Faktor pengalaman bertani juga ikut mempengaruhi pendapatan, semakin lama atau berpengalaman seseorang dalam bertani, maka akan semakin tinggi pula pendapatan yang diterima. Hal ini sesuai dengan teori Asih (2009), pengalaman usahatani akan dapat memotivasi petani untuk meningkatkan pendapatan. Fenomena yang terjadi di lokasi penelitian yaitu Marlina dan Fakriah yang berpengalaman 8 dan 9 tahun, namun pendapatan yang dihasilkan Marlina masih lebih rendah daripada Fakriah.

Biaya produksi berbanding lurus sebagai variabel yang mempengaruhi pendapatan, semakin efesien biaya yang dikeluarkan, maka pendapatan bersih yang diterima semakin lebih besar, jumlah produksi padi yang tinggi, ketika dihitung dengan uang akan meningkatkan pendapatan, dengan masyarakat harga beli gabah tetap tinggi. Hal ini sesuai dengan teori Damanik (2014) menyatakan biaya produksi mampu meningkatkan pendapatan. Fenomena yang terjadi adalah biaya produksi yang dikeluarkan Marlina lebih besar daripada Nurma, namun pendapatan yang dihasilkan lebih rendah daripada Nurma. Hal ini disebabkan biaya produksi yang dikeluarkan oleh Marlina tidak efesien terutama untuk biaya tenaga kerja dan biaya penyiangan gulma.

Selanjutnya yaitu variabel jumlah
produksi.
menyatakan jika jumlah produksi tinggi, maka pendapatan petani juga tinggi. Fenomena yang terjadi di Kecamatan Samudera adalah jumlah produksi Marlina lebih tinggi daripada Fakriah, namun pendapatan Marlina lebih rendah dibandingkan Fakriah. Hal ini disebabkan harga jual gabah Fakriah lebih tinggi dibandingkan dengan Marlina karena kualitas gabah hasil panen milik Fakriah lebih baik.

Dimana penelitian ini bertujuan untuk mengetahui Faktor-faktor yang Mempengaruhi Pendapatan Petani Padi Wanita di Kecamatan Samudera Kabupaten Aceh Utara.

Selanjutnya bagian kedua penelitian ini membahas kajian teoritis variabel-variabel terkait, bagian ke tiga merupakan pembahasan metodelogi penelitian. Untuk melihat hasil dan pembahasan di bagian ke empat dari penelitian ini, selanjutnya pembahasan bagian ke lima merupakan kesimpulan dan saran.

\section{KAJIAN TEORITIS Pendapatan}

Tujuan pokok dijalankannya suatu usaha adalah untuk memperoleh pendapatan, dimana pendapatan tersebut dapat digunakan untuk memenuhi kebutuhan hidup dan kelangsungan hidup usaha. Pendapatan juga bisa digunakan sebagai alat untuk mengukur kondisi ekonomi seseorang atau rumah tangga. Pendapatan dapat 
adalah jumlah penghasilan yang diterima oleh penduduk atas prestasi kerjanya selama satu periode tertentu, baik harian, mingguan, bulanan maupun tahunan (Sukirno,2006).

Pendapatan menunjukkan jumlah uang yang diterima oleh rumah tangga selama kurun waktu tertentu (biasanya satu tahun), Pendapatan terdiri dari upah atau penerimaan tenaga kerja, pendapatan dari kekayaan seperti sewa, bunga dan deviden, serta pembayaran transfer atau penerimaan dari pemerintah seperti tunjangan sosial atau asuransi pengangguran (Samuelson dan Nordhaus, 2001).

faktor-faktor produksi (sumber daya alam, tenaga kerja, dan modal) masing-masing dalam bentuk sewa, upah dan bunga, maupun laba, secara berurutan (Jaya, 2011). Pendapatan atau income dari seorang warga masyarakat adalah hasil "penjualan"nya dari faktor-faktor produksi yang dimilikinya kepada sektor produksi. (Boediono, 2000)

Dari definisi tersebut jelas bahwa setiap rumah tangga yang terdapat dalam perekonomian tiga sektor pada umumnya mereka memperoleh pendapatan dari kegiatan ekonomi yang berlangsung di pasar. Bagi rumah tangga konsumsi mereka akan mendapatkan pendapatan yang berasal dari penyediaan faktor-faktor produksi (sumber daya alam, tenaga kerja, dan modal) masing-masing dalam bentuk sewa, upah dan bunga, maupun laba. Untuk rumah tangga produksi, mereka akan memperoleh pendapatan dari keuntungan menjual barang dan jasa. Sedangkan rumah tangga pemerintah akan memperoleh pendapatan dari pajak ataupun retribusi atas prasarana dan kebijakan yang sudah diberikan atau disediakan.

Dari uraian di atas dapat disimpulkan bahwa pendapatan adalah jumlah seluruh uang yang diterima oleh seseorang atau rumah tangga sebagai imbalan balas jasa atas apa yang ia berikan ataupun korbankan selama jangka waktu tertentu.

\section{Definisi Modal}

Modal usaha adalah uang yang dipakai sebagai pokok (induk) untuk berdagang, melepas uang, dan sebagainya; harta benda (uang, barang, dan sebagainya) yang dapat dipergunakan untuk menghasilkan sesuatu yang menambah kekayaan. Modal dalam pengertian ini dapat diinterpretasikan sebagai sejumlah uang yang digunakan dalam menjalankan kegiatan-kegiatan usaha (Nugraha, 2011).
Banyak kalangan yang memandang bahwa modal uang bukanlah segala-galanya dalam sebuah usaha.

Modal adalah barang yang diproduksi oleh sistem ekonomi yang digunakan sebagai input untuk memproduksi barang dan jasa di masa depan serta tidak hanya terbatas pada uang atau aset keuangan seperti obligasi dan saham, tetapi barang-barang fisik seperti pabrik, peralatan, persediaan dan aset tidak berwujud (Case and Fair, 2007).

Dari uraian di atas dapat disimpulkan bahwa modal adalah segala sesuatu yang digunakan/dimanfaatkan untuk memproduksi barang dan jasa. Sedangkan yang dimaksud modal dalam penelitian ini adalah besarnya dana yang digunakan pedagang untuk menyediakan barang dagangnya pada setiap harinya. Satuan modal usaha ini dinyatakan dalam bentuk rupiah yang dikeluarkan pedagang setiap harinya.

\section{Luas Lahan}

Luas lahan usahatani adalah penguasaan lahan oleh petani, luasnya lahan usahatani akan mempengaruhi petani dalam menerapkan teknologi yang didapat dari kegiatan penyuluhan. Faktor kemampuan ekonomi yang dominan bagi petani adalah luas lahan usahatani. Dan luas lahan mempunyai pengaruh terhadap partisipasi warga masyarakat desa dalam pembangunan pedesaan. Hal ini diduga bahwa petani yang memiliki luas lahan yang luas relatif tergolong tinggi perhatiannya terhadap usahatani dan juga akan lebih berpengaruh besar karena merupakan tumpuan harapan keluarga dalam memenuhi kebutuhan hidupnya sehari-hari (Mubyarto, 2003).

Penggunaan luas lahan tanaman semusim diutamakan untuk tanaman musiman yang dalam polanya dapat dengan rotasi atau tumpang sari dan panen dilakukan setiap musim dengan periode biasanya kurang dari setahun. Penggunaan luas lahan tanaman tahunan merupakan penggunaan tanaman jangka panjang yang pergilirannya dilakukan setelah hasil tanaman tersebut secara ekonomi tidak produktif lagi, seperti pada tanaman perkebunan. Penggunaan luas lahan permanen diarahkan pada lahan yang tidak diusahakan untuk pertanian, seperti hutan, daerah konservasi, perkotaan, desa dan sarananya, lapangan terbang, dan pelabuhan. Secara nasional sumberdaya lahan sawah khususnya memiliki peranan penting dalam memproduksi bahan pangan. Sekitar 90 persen produksi padi nasional dihasilkan dari lahan sawah dan sisanya dari lahan kering (Irawan et al., 2005). 
Berdasarkan pendapat ahli di atas dapat disimpulkan bahwa luas lahan merupakan tanah yang dikuasai penggarapan oleh petani untuk ditanami padi pada musim tanam yang dapat dialiri dengan irigasi maupun non irigasi (tadah hujan) dan dapat dipergunakan secara terus menerus untuk usaha tani padi.

\section{Pengalaman Bertani}

Pengalaman banyaknya jenis pekerjaan atau jabatan yang pernah diemban oleh seseorang, serta lamanya mereka bekerja pada masing-masing pekerjaan (Sunuharyo, 2007). Pengalaman kerja akan mempengaruhi keterampilan seseorang dalam melaksanakan tugas dan juga membuat kerja lebih efisien (Cahyono, 2005). Hubungan pengalaman bertani dengan jumlah produksi memiliki hubungan yang positif dimana semakin lama pengalaman bertani dari seorang petani maka dapat dikatakan mampu petani tersebut sudah mampu menghadapi situasi atau hal-hal yang terjadi dalam kegiatan bertani (Sutarto, 2008).

Selain itu pengalaman bertani akan membantu para petani mengambil keputusan dalam melakukan usaha simantri. Semakin lama pengalaman bertani yang dimiliki oleh petani maka cenderung memiliki keterampilan tertinggi. Komponen penting dalam hal ini adalah karakteristik pribadi dari petani yang meliputi, pendidikan formal, pelatihan dan pengalaman (Damihartini 2005).

Pengalaman seseorang seringkali disebut sebagai guru yang baik, dimana dalam mempersepsi terhadap sesuatu obyek biasanya didasarkan atas pengalamannya.Pengalaman berusahatani tidak terlepas dari pengalaman yang pernah dia alami. Pengalaman petani dalam berusahatani merupakan salah satu faktor yang mempengaruhi tingkat adopsi inovasi pertanian (Syafruddin, 2003).

Berdasarkan pendapat di atas dapat disimpulkan bahwa pengalaman bertani merupakan lamanya seseorang melakukan pekerjaan sebagai petani padi, Pengalaman berusahatani terjadi karena pengaruh waktu yang telah dialami oleh petani. Petani yang berpengalaman dalam menghadapi hambatanhambatan usahataninya akan tahu cara mengatasinya. Lain halnya dengan petani yang belum atau kurang pengalaman, dimana akan mengalami kesulitan dalam menyelesaikan hambatan-hambatan tersebut.

\section{Biaya Produksi}

Biaya produksi adalah semua korbanan yang perlu dilakukan untuk suatu proses produksi, yang dinyatakan dengan satuan uang menurut harga pasar yang berlaku, baik yang sudah terjadi maupun yang akan terjadi. Dalam hal ini biaya terbagi menjadi dua, yaitu biaya tetap dan biaya variable. Biaya variabel (variable cost, $V C$ ) adalah biaya produksi yang berubah sesuai dengan level output yang diproduksi oleh petani. Sebagai contoh, selama satu musim usaha, biaya variabel yang digunakan untuk memproduksi telur adalah biaya yang dialokasikan untuk membeli input variabel seperti bibit, pakan dan obat-obatan. Anonymous (2010) .

Biaya produksi adalah jumlah uang yang dinyatakan dari sumber-sumber (ekonomi) yang dikorbankan untuk terjadinya suatu proses untuk rnendapatkan sesuatu atau untuk mencapai tujuan tertentu. Biaya dibedakan menjadi beberapa macam, diantaranya : Biaya tetap (fixed cost) merupakan biaya penggunaannya tidak habis dalam satu kali produksi. Biaya variabel (variable cost) atau biaya-biaya berubah merupakan biaya yang berubah-ubah atau besar kecilnya sangat berpengaruh pada skala produksi (Hernanto, 2001).

Biaya produksi yaitu semua biaya yang berhubungan dengan fungsi produksi atau kegiatan pengolahan bahan baku menjadi suatu produk. Biaya produksi merupakan biaya-biaya yang terjadi untuk mengolah bahan baku menjadi produk jadi yang siap untuk dijual (Mulyadi, 2000).

Biaya operasional adalah biaya-biaya yang diperlukan atau dikeluarkan untuk kegiatan operasi suatu usaha atau industri serta untuk menjaga keberlanjutan kegiatan industri tersebut. Biaya ini terjadi berulang-ulang selama masa pakai atau umur ekonomis dari investasi tersebut.

Biaya operasional adalah seluruh biaya yang dikeluarkan selama proses produksi itu berlangsung (Choliq, 2009). Biaya operasional adalah biaya variabel (variable cost) yaitu biaya tidak tetap atau besar kecilnya sangat berpengaruh pada skala produksi (Anonymous, 2010). Biaya operasional adalah pengorbanan sumber ekonomis yang dilakukan dalam satuan uang yang telah terjadi atau kemungkinan akan tercapai untuk tujuan tersebut (Mulyadi, 2000).

Berdasarkan teori di atas dapat disimpulkan bahwa biaya produksi merupakan sejumlah uang yang dikeluarkan oleh petani untuk membiayai kebutuhan dalam usahatani padi 
berupa biaya tenaga kerja untuk pengolahan tanah, penyiangan gulma, dan biaya panen.

\section{Jumlah Produksi}

Produksi padi merupakan salah satu hasil bercocok tanam yang dilakukan dengan penanaman bibit padi dan perawatan serta pemupukan secara teratur sehingga menghasilkan suatu produksi padi yang dapat dimanfaatkan. Padi tersebut kemudian diproses menjadi beras, yang mana beras itu sendiri akan diolah menjadi nasi. Padi dapat menghasilkan beras sebagai bahan pokok nasi yang merupakan sumber kalori utama yang banyak mengandung unsur karbohidrat yang sangat tinggi sehingga sangat bermanfaat dan menjadikan sebagai bahan pangan utama, Bps (2019).

Jumlah produksi mengandung arti sebagai perbandingan antara hasil yang dicapai (output) dengan keseluruhan sumberdaya yang digunakan (input). Jumlah atau hasil produksi adalah suatu konsep yang menggambarkan hubungan antar hasil (jumlah barang dan jasa yang diproduksi) dengan sumber (tenaga kerja, bahan baku, modal, energi, dan lain-lain) yang dipakai untuk menghasilkan barang tersebut, Umar (2009).

Jumlah produksi dapat dikatakan meningkat jika dapat menghasilkan lebih banyak produk dalam waktu yang sama, atau dapat menghasilkan produk dengan jumlah yang sama dalam jangka waktu yang singkat. Dari pernyataan tersebut, terdapat dua cara meningkatkan jumlah produksi yaitu sebagai berikut: 1) Meningkatkan jumlah yang dihasilkan, 2) Mengurangi waktu yang dibutuhkan. Jumlah produksi digunakan sebagai pengukur seberapa baik sumber daya yang digunakan di dalam sebuah usahatani (Supriyono, 2004).

Berdasarkan teori di atas dapat disimpulkan bahwa jumlah produksi adalah banyaknya hasil panen padi yang diperoleh petani setelah melewati proses panen. Jumlah produksi padi dilihat dari bobot gabah yang telah dirontokkan dengan mesin penghilir atau secara tradisional.

\section{Hipotesis}

Berdasarkan masalah yang dikemukakan sebelumnya maka dirumuskan hipotesis sebagai berikut :

$\mathrm{H}_{1} \quad$ :Diduga Modal berpengaruh terhadap pendapatan petani padi wanita di Kecamatan Samudera Kabupaten Aceh Utara
$\mathrm{H}_{2} \quad$ :Diduga Luas lahan berpengaruh terhadap pendapatan petani padi wanita di Kecamatan Samudera Kabupaten Aceh Utara

$\mathrm{H}_{3} \quad$ :Diduga Pengalaman bertani berpengaruh terhadap pendapatan petani padi wanita di Kecamatan Samudera Kabupaten Aceh Utara

$\mathrm{H}_{4} \quad$ :Diduga Biaya produksi berpengaruh terhadap pendapatan petani padi wanita di Kecamatan Samudera Kabupaten Aceh Utara

$\mathrm{H}_{5} \quad$ :Diduga Jumlah produksi berpengaruh terhadap pendapatan petani padi wanita di Kecamatan Samudera Kabupaten Aceh Utara

\section{METODE PENELITIAN}

\section{Objek dan Lokasi Penelitian}

Objek penelitian ini adalah modal, luas lahan, pengalaman bertani, biaya produksi, jumlah produksi dan pendapatan. Penelitian ini akan dilakukan di Desa Pulo, Kitou, Madang dan Matang Tunong Kecamatan Samudera Kabupaten Aceh Utara.

\section{Populasi Dan Sampel}

Populasi adalah keseluruhan subyek penelitian (Suharsimi, 2002). Yang menjadi populasi dalam penelitian ini adalah seluruh petani padi wanita di Desa Pulo, Desa Kitou, Desa Madang, Desa Matang Tunong. Dengan demikian jumlah sampel terpilih sebanyak 51 orang.

\section{Teknik Pengumpulan Data}

Data yang digunakan dalam penelitian ini terdiri dari data primer. Data primer adalah data yang bersumber dari hasil penelitian lapangan yang diperoleh berdasarkan hasil jawaban para responden melalui penyebaran kuesioner yang telah disiapkan kepada seluruh responden yang selanjutnya diolah dan dianalisis oleh peneliti.

\section{Definisi Operasional Variabel Penelitian}

Berdasarkan rumusan hipotesis penelitian, variabel penelitian terdiri dari dua variabel $X$ sebagai variabel Independen dan Variabel $Y$ sebagai variabel dependen. Adapun variabelnya meliputi: modal, luas lahan, pengalaman bertani, biaya produksi, jumlah produksi dan pendapatan.

\section{Modal $\left(\mathrm{X}_{1}\right)$}

Modal adalah sejumlah pengeluaran yang dihabiskan oleh petani padi wanita untuk 
bertani padi, diukur dalam satuan Rupiah/panen.

2. Luas lahan $\left(\mathrm{X}_{2}\right)$

Luas lahan adalah ukuran lahan yang digunakan oleh petani padi wanita untuk menanam padi, diukur dalam satuan $\mathrm{Ha}$.

3. Pengalaman bertani $\left(\mathrm{X}_{3}\right)$

Pengalaman bertani adalah lamanya petani padi wanita menanam padi di sawah, diukur dalam satuan Tahun.

4. Biaya Produksi $\left(\mathrm{X}_{4}\right)$

Biaya Produksi adalah Jumlah biaya yang dikeluarkan petani padi wanita untuk sekali menanam, diukur dalam satuan $\mathrm{Rp} / \mathrm{panen}$.

5. Jumlah Produksi $\left(\mathrm{X}_{5}\right)$

Jumlah Produksi adalah Jumlah hasil panen yang diterima petani padi wanita untuk sekali menanam, diukur dalam satuan Ton/panen.

6. Pendapatan (Y)

Pendapatan adalah Jumlah uang yang diterima petani padi wanita dari penjualan hasil panen padi, diukur dalam satuan $\mathrm{Rp} /$ panen.

\section{Uji Normalitas}

Untuk mendeteksi normal atau tidak normalnya model regresi dapat dilakukan dengan cara membandingkan nilai Jarque-Bera hitung dengan nilai $\mathrm{C}^{2}$ (Chi-Square) tabel. Menurut Winarno (2007) untuk mendeteksi apakah residualnya berdistribusi normal atau tidak dengan membandingkan nilai Jarque Bera dengan chisuquare.

\section{Uji Asumsi Klasik}

\section{Uji Multikolinieritas}

Multikolinieritas adalah hubungan yang sangat kuat antara variabel-variabel eksplanatoris dalam model regresi. Multikolinieritas mengakibatkan estimasi yang dihasilkan menjadi kurang tepat. Multikolinieritas ini dapat dideteksi dengan: Pertama, nilai determinasi yang tinggi dengan diikuti nilai $\mathrm{F}$ statistik yang sangat tinggi, serta tidak ada atau hanya sedikit nilai t-test yang signifikan. Kedua, koefisien matriks korelasi antara variabel yang tinggi $(>0.8)$.

Uji multikolinearitas dalam penelitian ini dianalisis melalui matriks korelasi dengan batas nilai 0,8 dan Variance Inflation Factor (VIF) dengan ambang maksimum tidak lebih dari 10 (Gujarati, 2008).

\section{Uji Heteroskedastisitas}

Heteroskedastisitas adalah keadaan dimana faktor gangguan tidak memiliki varian yang sama. Menurut Winarno, (2013) untuk mendeteksi ada tidaknya heteroskedastisitas dilakukan dengan melakukan perbandingan antara nilai observasi Rsquared dan tabel $\mathrm{X}^{2}$, yaitu sebagai berikut :

a. Jika nilai Obs*R-squared > chi-square tabel, maka menunjukkan adanya heteroskedastisitas.

b. Jika nilai Obs*R-squared < chi-square tabel, maka menunjukkan tidak adanya heteroskedastisitas.

\section{Metode Analisis Data \\ Analisis Regresi Linier Berganda}

Untuk mengetahui apakah ada pengaruh yang signifikan dari variabel independen terhadap variabel dependen maka digunakan model regresi linier berganda.

$$
\begin{aligned}
& Y=\alpha+\beta_{1} X_{1}+\beta_{2} X_{2}+\beta_{3} X_{3}+\beta_{4} X_{4}+\beta_{5} X_{5}+e \\
& \mathrm{Y}=\text { Pendapatan }(\mathrm{Rp}) \\
& \mathrm{X}_{1} \quad=\text { Modal }(\mathrm{Rp}) \\
& \mathrm{X}_{2} \quad=\text { Luas Lahan }(\mathrm{Ha}) \\
& \mathrm{X}_{3} \quad=\text { Pengalaman Bertani } \\
& \mathrm{X}_{4} \quad=\text { Biaya Produksi (Rp) } \\
& \mathrm{X}_{5} \quad=\text { Jumlah Produksi (Ton) } \\
& \alpha \quad=\text { Konstanta } \\
& \beta_{1}, \beta_{2}, \beta_{3}, \beta_{4}, \beta_{5}=\text { Koefesien regresi } \\
& \mathrm{e}=\text { Error term }
\end{aligned}
$$

Dikarenakan variabel-variabel yang digunakan tidak memiliki satuan yang sama, maka diubah dalam bentuk logaritma (Log). Adapun rumus analisis data adalah sebagai berikut:

$$
\begin{aligned}
& \log Y=\alpha+\beta_{1} \log X_{1}+\beta_{2} X_{2}+\beta_{3} X_{3}+\beta_{4} \\
& \log X_{4}+\beta_{5} \log X_{5}+e
\end{aligned}
$$

\section{Koefesien Korelasi (R)}

Koefesien korelasi dinyatakan dalam nilai koefisien korelasi (r). Menurut Ghozali (2007): jika koefisien korelasi bernilai 0,70 sampai mendekati 1,00 (plus atau minus) menunjukkan derajat hubungan yang tinggi, koefisien korelasi lebih besar dari 0,40 sampai di bawah 0,70 (plus atau minus) menunjukkan derajat hubungan yang sedang, apabila koefisien korelasinya di atas 0,20 sampai 0,40 (plus atau minus) maka menunjukkan derajat hubungan yang rendah.

\section{Koefesien Determinan $\left(\mathbf{R}^{\mathbf{2}}\right)$}

Analisis ini dipergunakan untuk mengetahui proporsi variabel independen dalam memberikan kontribusinya terhadap variabel dependen dan 
hasil perhitungan dari analisis ini berupa prosentase. Untuk mengetahui nilai koofisien determinasi dapat diketahui dari nilai adjusted $R$ square pada tabel model summary . $^{b}$

\section{Pengujian Hipotesis \\ Uji-t (Uji Parsial)}

Untuk mengetahui pengaruh variabel bebas secara parsial atau individu terhadap variabel tidak bebas dengan asumsi variabel yang lain konstan. Pengujian ini dilakukan dengan melihat derajat signifikan masing-masing variabel bebas menggunakan Eviews.

Jika $\mathrm{t}$ hitung $>\mathrm{t}$ tabel maka hipotesis menyatakan menerima $\mathrm{H}_{\mathrm{a}}$ secara parsial dengan tingkat signifikan $<\alpha=0,05$. Dasar pengambilan keputusan:

a. Jika probabilitas (signifikan) $<0,05(\alpha)$ maka $\mathrm{H}_{\mathrm{a}}$ diterima secara parsial.

b. Jika probabilitas (signifikan) $<0,05(\alpha)$ maka $\mathrm{H}_{\mathrm{a}}$ ditolak secara parsial.

Pada derajat keyakinan (level significant $)=$ $5 \%$, apabila $\mathrm{t}$ hitung $>\mathrm{t}$ tabel maka variabel bebas berpengaruh secara parsial terhadap variabel terikat. Sebaliknya, apabila $\mathrm{t}$ hitung $<\mathrm{t}$ tabel maka hipotesis ditolak, berarti bahwa variabel bebas tidak berpengaruh terhadap variabel terikat.

\section{Uji - F (Uji Simultan)}

1. Jika Fhitung < Ftabel, maka $\mathrm{H}_{\mathrm{o}}$ diterima artinya secara statistik dapat dibuktikan bahwa variabel independent tidak berpengaruh terhadap variabel dependent.

2. Jika Fhitung > Ftabel, maka $\mathrm{H}_{\mathrm{o}}$ ditolak dan $\mathrm{H}_{\mathrm{a}}$ (hipotesis alternatif) diterima, artinya secara simultan dapat dibuktikan semua variabel independent (berpengaruh terhadap variabel dependent .

\section{Koefisien Korelasi}

Koefisien korelasi adalah nilai yang menunjukkan kuat atau tidaknya hubungan antar variabel.

\section{HASIL PENELITIAN DAN PEMBAHASAN}

Uji normalitas data dilakukan untuk melihat apakah dalam model regresi, variabel dependen dan variabel independennya memiliki distribusi normal atau tidak (Ikhsan, 2014), Pengujian ini dimaksudkan untuk mengetahui apakah dalam model regresi variabel pengganggu atau residual mempunyai distribusi normal.
Berikut adalah hasil uji normalitas yang diperoleh dari program Eviews 9 dapat dilihat pada gambar berikut ini:

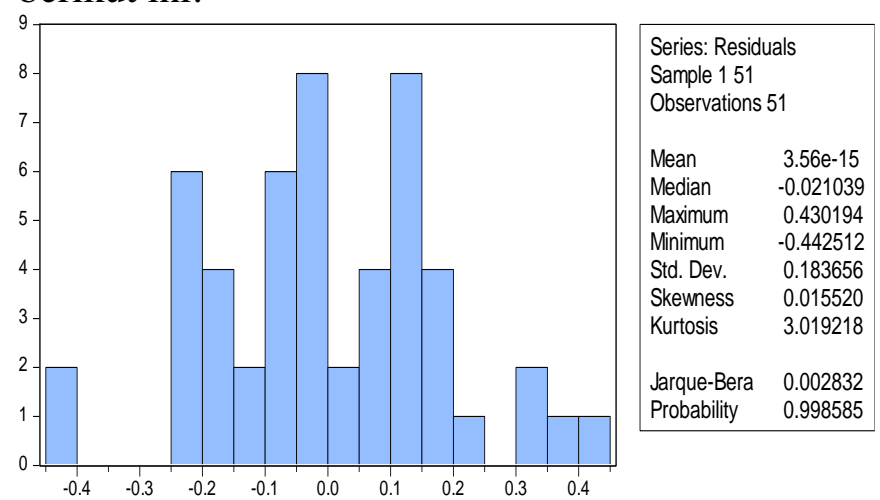

Sumber : Hasil Eviews, data diolah (2019)

Dari gambar diatas dapat dilihat bahwa residual penelitian berdistribusi normal dimana nilai Jarque-Bera lebih kecil dari nilai chi square pada $\alpha=5 \%$ yaitu 0,002 lebih kecil dari 11,07 . Hasil ini sesuai dengan pendapat Winarno (2007) yang menyatakan bahwa Jika hasil uji jarque-bera lebih kecil dari nilai chi square pada $\alpha=5 \%$, yang berarti data berdistribusi normal.

Pengujian juga dapat dibuktikan Jika nilai probabilitas signifikansinya di atas 0,05 maka berarti nilai residual berdistribusi normal. Hasil penelitian ini menunjukkan bahwa probabilitas sebesar 0,998 lebih besar dari 0,05, sehingga dapat disimpulkan bahwa data terdistribusi normal.

\section{Uji Multikolinieritas}

Multikolinieritas berhubungan dengan situasi dimana ada hubungan linier baik yang pasti atau mendekati pasti diantara variabel independen (Widarjono, 2013). Multikolinieritas ini bertujuan untuk mengetahui apakah maing-masing variabel bebas saling berhubungan secara linier dalam model persamaan regresi yang digunakan. Hasil uji Multikolinieritas dapat dilihat pada Tabel 2 Berikut ini :

\section{Tabel 1}

Hasil Uji Multikolinieritas

\begin{tabular}{lcc}
\hline \hline \multicolumn{1}{c}{ Variable } & $\begin{array}{c}\text { Uncentered } \\
\text { VIF }\end{array}$ & $\begin{array}{c}\text { Centered } \\
\text { VIF }\end{array}$ \\
\hline \hline Modal & 38.36145 & 2.586190 \\
Pengalaman bertani & 6.415671 & 1.752206 \\
Luas_Lahan & 10.74539 & 1.647655 \\
Biaya_Produksi & 15.47678 & 2.246063 \\
Jumlah_Produksi & 20.75206 & 1.445755 \\
C & 21.52643 & NA \\
\hline \hline
\end{tabular}

Sumber : Hasil eviews, 2019

Berdasarkan Tabel 2 dapat dilihat tidak terdapat sel antar variabel bebas yang memiliki nilai di atas 10, maka dapat dikatakan bahwa 
seluruh variabel bebas dalam penelitian ini tidak saling berkorelasi dan penelitian ini bebas dari gejala multikolinearitas.

\section{Uji Heteroskedastisitas}

Heteroskedastisitas terjadi pada saat residual dan nilai prediksi memiliki korelasi atau pola hubungan. Untuk mendeteksi heteroskedastisitas yaitu :

c. Jika nilai Obs*R-squared $>\chi^{2}$ (chi-square) tabel, maka tidak lolos dari uji heteroskedastisitas.

d. Jika nilai Obs*R-squared $<\chi^{2}$ (chi-square) tabel, maka lolos dari uji heteroskedastisitas.

\section{Tabel 3}

\section{Hasil Uji Heteroskedastisitas}

Heteroskedasticity Test: White

\begin{tabular}{llll}
\hline \hline F-statistic & 0.412211 & Prob. F(5,45) & 0.8378 \\
Obs*R-squared & 2.233562 & Prob. Chi-Square(5) & 0.8160 \\
Scaled explained SS & 1.755642 & Prob. Chi-Square(5) & 0.8818 \\
\hline \hline
\end{tabular}

Sumber : Data diolah, (2019)

Dari hasi tabel 3 di atas dapat dilihat bahwa nilai obs* R-square untuk hasil estimasi uji white adalah sebesar 2,22 dan nilai $\chi^{2}$ tabel dengan derajat kepercayaan 5\% dan df (6) adalah 7,81 karena nilai Obs*R-squared 2,22 < 7,81 maka dapat disimpulkan bahwa model diatas lolos dari heteroskedastisitas. Hal ini juga dapat dilihat dari probabilitas Chi-Squared sebesar 0,816, nilai tersebut $0,816>0,05$.

\section{Analisis Regresi Linier Berganda}

Berdasarkan dari hasil Uji analisis regresi linier berganda dengan alat bantu komputer yang menggunakan program Eviesw 8, dapat dilihat pada Tabel 4 sebagai berikut :

Tabel. 4

Hasil Analisis Regresi Linier Berganda

\begin{tabular}{lrrrr}
\hline \hline \multicolumn{1}{c}{ Variable } & Coefficient & Std. Error & t-Statistic & Prob. \\
\hline \hline C & 2.206203 & 1.674208 & 1.317759 & 0.1943 \\
Log(Modal) & 1.106384 & 0.179552 & 6.161903 & 0.0000 \\
Luas_Lahan & 0.291992 & 0.142484 & 2.049292 & 0.0463 \\
Pengalaman Bertani & 0.014009 & 0.005339 & 2.624020 & 0.0118 \\
Log(Biaya_Produksi) & -0.305466 & 0.121505 & -2.514023 & 0.0156 \\
Log(Jumlah_Produksi) & 0.095048 & 0.115183 & 0.825194 & 0.4136 \\
\hline \hline
\end{tabular}

R-squared

Adjusted R-squared

S.E. of regression

Sum squared resid

Log likelihood

$\begin{array}{lll}0.745264 & \text { Mean dependent var } & 15.03176 \\ 0.716960 & \text { S.D. dependent var } & 0.363883 \\ 0.193591 & \text { Akaike info criterion } & -0.336009 \\ 1.686484 & \text { Schwarz criterion } & -0.108735 \\ 14.56822 & \text { Hannan-Quinn criter. } & -0.249161\end{array}$

Sumber : Eviews 8, data diolah (2019)

Dari tabel 4.3 di atas maka model regresi linier berganda adalah sebagai berikut :

$$
\begin{aligned}
\log Y= & 2,206203+1,106384 \log X_{1}+0, \\
& 291992 X_{2}+0,014009 X_{3}-0,305466 \log \\
& X_{4}+0,095048 \log X_{5}
\end{aligned}
$$

Dari hasil diatas dapat di interpretasi hasil analisis regresi linier berganda yaitu sebagai berikut :

1. Konstanta mempunyai nilai 2,206203, menunjukkan apabila variabel independen yang terdiri dari modal, luas lahan, pengalaman bertani, biaya produksi dan jumlah produksi memiliki nilai nol maka pendapatan yang diterima petani adalah sebesar 2, 206203\%.

2. Koefisien variabel modal $\left(\mathrm{X}_{1}\right)$ mempunyai nilai sebesar 1,106384, Hal ini menunjukkan hubungan yang positif. Artinya apabila modal $\left(\mathrm{X}_{1}\right)$ meningkat $1 \%$ maka pendapatan $(\mathrm{Y})$ juga akan meningkat sebesar $1,106384 \%$.

3. Koefisien variabel luas lahan $\left(\mathrm{X}_{2}\right)$ mempunyai nilai sebesar 0,291992, Hal ini menunjukkan hubungan yang positif. Artinya apabila luas lahan $\left(\mathrm{X}_{1}\right)$ meningkat 1 ha maka pendapatan (Y) juga akan meningkat sebesar 0,291992\% .

4. Koefisien variabel pengalaman bertani $\left(X_{3}\right)$ mempunyai nilai sebesar 0,014009, Hal ini menunjukkan hubungan yang positif. Artinya apabila pengalaman bertani $\left(\mathrm{X}_{3}\right)$ meningkat 1 tahun maka pendapatan (Y) juga akan meningkat sebesar 0,014009\% .

5. Koefisien variabel biaya produksi $\left(\mathrm{X}_{4}\right)$ mempunyai nilai sebesar - 0,305466, Hal ini menunjukkan hubungan yang negatif. Artinya apabila biaya produksi $\left(\mathrm{X}_{4}\right)$ meningkat $1 \%$ maka pendapatan (Y) juga akan menurun sebesar 0,305466\% .

6. Koefisien variabel jumlah produksi ( $\left.\mathrm{X}_{5}\right)$ mempunyai nilai sebesar 0,095048, Hal ini menunjukkan hubungan yang positif. Artinya apabila jumlah produksi $\left(\mathrm{X}_{5}\right)$ meningkat $1 \%$ maka pendapatan (Y) akan meningkat sebesar $0,095048 \%$

\section{Pengujian Hipotesis Pengujian Parsial (Uji t)}

Penelitian ini menggunakan uji t sebagai pengujian hipotesis. Uji t digunakan untuk melihat pengaruh variabel independen terhadap variabel dependen secara parsial. Adapun kriteria pengambilan keputusannya yaitu dengan melihat 
nilai $\mathrm{t}$ hitung dengan membandingkannya dengan nilai $t$ tabel kemudian juga melihat nilai signifikansinya. Uji ini dilakukan dengan membandingkan nilai $\mathrm{t}$ hitung dengan $\mathrm{t}$ tabel dengan cara df $(n-k-1)=(51-5-1)=45$ pada $\alpha$ : $5 \%$ adalah sebesar 1,679 .

Berdasarkan hasil pengujian secara parsial pada tabel 4.4 dapat dijelaskan bahwa :

1. Modal $\left(\mathrm{X}_{1}\right)$ berpengaruh terhadap Pendapatan (Y). Hal ini didasarkan pada nilai $\mathrm{t}_{\text {hitung }}>\mathrm{t}$ tabel yakni $6,161>1,679$ maka terima $\mathrm{H}_{1}$. Hal ini juga bisa dilihat dari probabilitas hitung $<\mathrm{p}-$ value atau $0.000<$ 0.05 .

2. Luas lahan $\left(\mathrm{X}_{2}\right)$ berpengaruh terhadap Pendapatan (Y). Hal ini didasarkan pada nilai $\mathrm{t}_{\text {hitung }}>\mathrm{t}_{\text {tabel }}$ yakni 2,049>1,679 maka terima $\mathrm{H}_{2}$. Hal ini juga bisa dilihat dari probabilitas hitung $<\mathrm{p}-$ value atau $0.046<$ 0.05 .

3. Pengalaman bertani $\left(\mathrm{X}_{3}\right)$ berpengaruh terhadap Pendapatan (Y). Hal ini didasarkan pada nilai $\mathrm{t}_{\text {hitung }}>\mathrm{t}$ tabel yakni 2,624 >1,679 maka terima $\mathrm{H}_{3}$. Hal ini juga bisa dilihat dari probabilitas hitung < p - value atau $0.011<$ 0.05 .

4. Biaya Produksi $\left(\mathrm{X}_{4}\right)$ berpengaruh negatif terhadap Pendapatan (Y). Hal ini didasarkan pada nilai $\mathrm{t}$ hitung $>\mathrm{t}$ tabel yakni 2,514 $>1,679$ maka terima $\mathrm{H}_{4}$. Hal ini juga bisa dilihat dari probabilitas hitung $<\mathrm{p}-$ value atau $0.015<$ 0.05 .

5. Jumlah Produksi $\left(\mathrm{X}_{5}\right)$ tidak berpengaruh terhadap Pendapatan (Y). Hal ini didasarkan pada nilai $\mathrm{t}_{\text {hitung }}<\mathrm{t}$ tabel yakni $0,825<1,679$ maka tolak $\mathrm{H}_{1}$. Hal ini juga bisa dilihat dari probabilitas hitung < p - value atau $0.413>$ 0.05 .

\section{Pengujian Simultan (Uji F)}

Pengujian secara simultan di gunakan untuk melihat pengaruh secara keseluruhan antara modal, luas lahan, pengalaman, biaya produksi dan jumlah produksi terhadap Pendapatan. Berdasarkan hasil pengujian pada tabel di atas maka dapat dilihat bahwa nilai $F_{\text {hitung }}$ sebesar 26,330 dengan probabilitas sebesar 0,0000, sedangkan $\mathrm{f}_{\text {tabel }}$ pada $\mathrm{df}=(\mathrm{k}-1)(\mathrm{n}-\mathrm{k})=(5-1)(51-5)$ $=$ (4) (46) yaitu sebesar 2,574 dari $\alpha=5 \%$, maka $F_{\text {hitung }}>F_{\text {tabel }}$ yaitu 26,330 $>2,574$. Hal ini juga dapat dilihat dari probabilitas sebesar $0,0000<$ 0,05. Maka dapat disimpulkan bahwa $\mathrm{H}_{5}$ diterima artinya secara simultan modal, luas lahan, pengalaman bertani, biaya produksi dan jumlah produksi berpengaruh terhadap pendapatan (Y).

\section{Koefisien Determinasi $\left(\mathbf{R}^{2}\right)$ dan Korelasi $(\mathbf{R})$ Koefisien Determinasi $\left(\mathbf{R}^{2}\right)$}

Berdasarkan Tabel 4.4 diatas hasil uji Koefisien determinasi $\mathrm{R}^{2}$ dengan regresi linier berganda, maka yang di lihat dari Adjusted $R$ Square yaitu sebesar 0,7169 atau 71,69\%. Jadi besarnya pengaruh modal, luas lahan, pengalaman bertani, biaya produksi dan jumlah produksi terhadap pendapatan adalah sebesar 71,69\%. Sedangkan sisanya di pengaruhi oleh variabel lain diluar model sebesar 28,31\%.

\section{Koefisien Korelasi (R)}

Koefisien Korelasi (R) dapat diperoleh dari $\mathrm{R}=\sqrt{R^{2}}=\sqrt{0,7169}=0,8466$. Jadi hubungan antara modal, luas lahan, pengalaman bertani, biaya produksi dan jumlah produksi terhadap pendapatan (Y) berpengaruh kuat secara positif, karena nilai korelasi sebesar 84,66 mendekati $(+1)$.

\section{Pembahasan \\ Pengaruh Modal Terhadap pendapatan}

Dari hasil penelitian yang telah dilakukan dapat dilihat bahwa modal kerja berpengaruh positif dan signifikan terhadap pendapatan Petani padi Wanita di Kecamatan Samudera. Hal ini ditunjukkan oleh hasil nilai $\mathrm{t}$ hitung $>\mathrm{t}$ tabel yakni $6,161>1,679$ dan nilai signifikan sebesar $0.000<$ 0.05 . Dengan demikian penelitian ini menerima $\mathrm{H}_{1}$ yang berarti bahwa variabel modal kerja berpengaruh positif dan signifikan terhadap pendapatan petani padi.

Modal adalah semua bentuk kekayaan yang dapat digunakan langsung maupun tidak langsung dalam proses produksi untuk menambah output. Dalam pengertian ekonomi, modal yaitu barang atau uang yang bersama-sama faktor- faktor produksi tanah dan tenaga kerja menghasilkan barang-barang dan jasa-jasa baru. Modal atau biaya adalah salah satu faktor yang sangat penting bagi setiap usaha, baik skala kecil, menengah maupun besar, Tambunan (2002). Sedangkan Modal adalah jumlah uang yang digunakan pada saat awal membuka usaha untuk membeli barang dagangan yang akan dijual kembali dan dinyatakan dalam rupiah.

Menurut Laili, (2008) dimana semakin besar atau meningkatnya modal yang dimiliki maka pendapatan yang diperoleh akan semakin meningkat dan sebaliknya jika modal yang dimiliki kecil atau menurun maka pendapatan yang diperoleh pun akan menurun. Modal kerja merupakan faktor yang penting dalam kegiatan usaha, sebab modal kerja disini merupakan urat 
nadi bagi kelangsungan suatu perusahaan. Semakin besar modal kerja, maka semakin luas kesempatan untuk mengambangkan usaha. Uang atau dana yang dikeluarkan dari modal kerja tersebut dapat diharapkan kembali lagi dalam jangka waktu yang pendek, melalui hasil penjualan produk tersebut akan segera dikeluarkan lagi untuk membiayai operasi selanjutnya, jadi jika modal kerja bertambah maka otomatis akan mempengaruhi keuntungan (Nazir, 2003).

Hasil penelitian yang dilakukan oleh Firdausa dan Arianty (2013), Ikramuddin dan Wahyuddin (2012), Puspita (2013) dan priyandika (2014) yang menyimpulkan bahwa modal kerja berpengaruh terhadap peningkatan pendapatan. Semakin besar modal yang di miliki oleh pedagang maka semakin besar pula kemampuan pedagang tersebut untuk memperoleh pendapatan. Modal merupakan alat untuk memupuk pendapatan maka akan menciptakan dorongan dan minat untuk menyisihkan kekayaannya maupun hasil produksi dengan maksud yang produktif dan tidak untuk maksud keperluan yang konsumtif.

\section{Pengaruh Luas Lahan Terhadap pendapatan}

Dari hasil penelitian yang telah dilakukan dapat dilihat bahwa Luas lahan berpengaruh positif dan signifikan terhadap pendapatan Petani padi Wanita di Kecamatan Samudera. Hal ini ditunjukkan oleh hasil nilai $\mathrm{t}$ hitung $>\mathrm{t}$ tabel yakni $2,049>1,679$ dan nilai signifikan sebesar $0.04<$ 0.05. Dengan demikian penelitian ini menerima $\mathrm{H}_{2}$ yang berarti bahwa variabel luas lahan berpengaruh positif dan signifikan terhadap pendapatan petani padi.

Luas Lahan akan mempengaruhi skala usaha yang pada akhirnya akan mempengaruhi besar atau kecilnya jumlah produksi suatu usaha pertanian. Besar atau kecilnya jumlah produksi suatu usaha pertanian akan mempengaruhi pendapatan petani, yang mana petani yang mempunyai luas lahan yang luas akan mendapatkan hasil produksi yang banyak sehingga memperoleh penghasilan yang banyak pula, sedangkan petani yang memiliki luas lahan yang sedikit maka produksinya juga sedikit dan akan memperoleh penghasilan yang sedikit pula.

Luas lahan adalah besarnya luasan lahan yang dikelola dalam berusaha tani untuk menghasilkan produksi. Semakin luas lahan yang di gunakan maka produksi yang dihasilkan semakin meningkat. Menurut Hernanto (2001) bahwa tanah yang sempit merupakan kelemahan yang cukup besar bagi petani, dengan kata lain usahatani pada lahan yang sempit kurang dapat memberikan keuntungan yang cukup bagi petani dan keluarga untuk hidup layak, sebaliknya semakin tinggi suatu luas lahan, maka kecenderungan untuk menghasilkan produksi semakin tinggi.

Hasil penelitian ini sejalan dengan penelitian yang dilakukan oleh Maryoni (2016), Arimbawa dan Windata (2017), Rangkuti, Siregar, Thamrin dan Andriano (2014), Rabiaton (2013), Sumiana(2017) yang menyimpulkan bahwa luas lahan berpengaruh positif terhadap Pendapatan, hal ini menunjukkan bahwa Semakin tinggi luas lahan maka semakin tinggi pendapatan petani padi.

\section{Pengaruh Pengalaman bertani Terhadap pendapatan}

Dari hasil penelitian yang telah dilakukan dapat dilihat bahwa pengalaman bertani berpengaruh positif dan signifikan terhadap pendapatan Petani padi Wanita di Kecamatan Samudera. Hal ini ditunjukkan oleh hasil nilai $\mathrm{t}$ hitung > t tabel yakni 2,624>1,679 dan nilai signifikan sebesar $0.01<0.05$. Dengan demikian penelitian ini menerima $\mathrm{H}_{3}$ yang berarti bahwa variabel pengalaman berpengaruh positif dan signifikan terhadap pendapatan petani padi. Adanya pengaruh positif menunjukkan apabila semakin lama usaha yang di jalankan maka akan semakin besar pula pendapatan yang di terima petani padi.

Hasil penelitian ini mendukung pendapat Sukirno (2004) Lamanya suatu usaha dapat menimbulkan pengalaman berusaha, dimana pengalaman dapat mempengaruhi pengamatan seseorang dalam bertingkah laku. Lama pembukaan usaha dapat mempengaruhi tingkat pendapatan, lama seorang pelaku bisnis menekuni bidang usahanya akan mempengaruhi produktivitasnya. Semakin lama menekuni bidang usaha perdagangan akan makin meningkatkan pengetahuan tentang selera ataupun perilaku konsumen.

Lamanya seorang pelaku bisnis menekuni bidang usahanya akan mempengaruhi kemampuan profesionalnya. Semakin lama menekuni bidang usaha perdagangan akan makin meningkatkan pengetahuan tentang selera ataupun perilaku konsumen. Ketrampilan berdagang makin bertambah dan semakin banyak pula relasi bisnis maupun pelanggan yang berhasil dijaring (Asmie, 2008:18).

Hasil penelitian Firdausa dan Arianti (2014) menunjukkan bahwa Variabel lama usaha berpengaruh terhadap jumlah pendapatan 
pedagang kios di pasar Bintoro Demak. Hasil penelitian Prisatya (2013) menunjukkan bahwa pengalaman usaha berpengaruh terhadap pendapatan pedagang. Menurut Ranupandjojo (1984) dalam Prisatya (2013) mengemukakan pengalaman usaha adalah ukuran tentang lama waktu atau masa kerja yang telah ditempuh seseorang agar dapat memahami tugas - tugas suatu pekerjaan dengan baik. Pengalaman usaha menentukan keterampilan seseorang dalam melaksanakan suatu tugas tertentu, dan pengalaman usaha dapat berdampak positif atau negatif terhadap kemampuan seseorang. tersebut, sehingga dapat mengembangkan bisnis usaha dengan lebih baik lagi.

\section{Pengaruh Biaya Produksi pendapatan \\ Terhadap}

Dari hasil penelitian yang telah dilakukan dapat dilihat bahwa biaya produksi berpengaruh negatif dan signifikan terhadap pendapatan Petani padi Wanita di Kecamatan Samudera. Hal ini ditunjukkan oleh hasil nilai $\mathrm{t}$ hitung $>\mathrm{t}$ tabel yakni $2,514>1,679$ dan nilai signifikan sebesar $0.01<$ 0.05 . Dengan demikian penelitian ini menerima $\mathrm{H}_{4}$ yang berarti bahwa variabel biaya produksi berpengaruh negatif dan signifikan terhadap pendapatan petani padi.

Biaya operasional atau biaya operasi adalah biaya-biaya yang tidak berhubungan langsung dengan kegiatan pertanian tetapi berkaitan dengan aktivitas operasional sehari-hari biaya operasional diartikan sebagai biaya yang terjadi dalam kaitannya dengan operasi yang dilakukan dan diukur dalam satuan uang. Semakin rendah dan efesien biaya operasional maka semakin tinggi pendapatan yang didapat petani padi, semakin luas lahan maka semakin tinggi biaya operasionalnya. Dengan menggunakan biaya operasional yang optimal diharapkan mampu meningkatkan pendapatan petani.

Hasil penelitian ini sejalan dengan penelitian yang dilakukan oleh Jannah dan Rivandi (2017) yang menyimpulkan bahwa biaya operasional berpengaruh negatif terhadap pendapatan. Hasil penelitian Iswandi (2015), Felicia dan Gultom (2018), juga menyimpulkan bahwa bahwa biaya produksi berpengaruh negatif terhadap laba perusahaan.

\section{Pengaruh Jumlah Produksi Terhadap pendapatan}

Dari hasil penelitian yang telah dilakukan dapat dilihat bahwa jumlah produksi tidak berpengaruh terhadap pendapatan Petani padi Wanita di Kecamatan Samudera. Hal ini ditunjukkan oleh hasil nilai $\mathrm{t}$ hitung $>\mathrm{t}$ tabel yakni $0,825>1,679$ dan nilai signifikan sebesar $0.181<$ 0.05 . Dengan demikian penelitian ini menolak $\mathrm{H}_{5}$ yang berarti bahwa variabel jumlah produksi tidak berpengaruh terhadap pendapatan petani padi.

Jumlah produk merupakan salah satu faktor yang mempengaruhi pendapatan yang akan di hasilkan oleh petani. Setiap petani mempunyai kebijaksanaan yang berbeda-beda dalam menggunakan hasil produksi. Sebagian petani hasil dari jumlah produksi padi yang dihasilkan digunakan untuk kebutuhan pokok keluarga dimana padi merupakan kebutuhan pangan yang harus di penuhi setiap hari. Oleh sebab itu banyak petani yang tidak menjual hasil produksi padi sehingga tidak berdampak pada peningkatan pendapatan.

Hasil penelitian sejalan dengan penelitian yang dilakukan oleh Kadim, Masinambaouw dan Sumual (2017) menunjukkan bahwa jumlah produksi tidak berpengaruh terhadap pendapatan.

\section{Penutup \\ Kesimpulan}

Berdasarkan hasil penelitian dan pembahasan, maka peneliti mengemukakan kesimpulan sebagai berikut :

6. Secara parsial Modal $\left(\mathrm{X}_{1}\right)$ berpengaruh positif dan signifikan terhadap Pendapatan (Y). Hal ini didasarkan pada nilai $\mathrm{t}_{\text {hitung }}>\mathrm{t}$ tabel yakni 6,065> 1,677 maka terima $\mathrm{H}_{1}$. Hal ini juga bisa dilihat dari probabilitas hitung $<\mathrm{p}-$ value atau $0.000<0.05$.

7. Luas lahan $\left(\mathrm{X}_{2}\right)$ berpengaruh positif dan signifikan terhadap Pendapatan (Y). Hal ini didasarkan pada nilai $\mathrm{t}$ hitung $>\mathrm{t}$ tabel yakni 2,301 > 1,677 maka terima $\mathrm{H}_{2}$. Hal ini juga bisa dilihat dari probabilitas hitung $<\mathrm{p}-$ value atau $0.026<0.05$.

8. Pengalaman $\left(\mathrm{X}_{3}\right)$ berpengaruh positif dan signifikan terhadap Pendapatan (Y). Hal ini didasarkan pada nilai $\mathrm{t}$ hitung $>\mathrm{t}$ tabel yakni 3,169>1,677 maka terima $\mathrm{H}_{3}$. Hal ini juga bisa dilihat dari probabilitas hitung $<\mathrm{p}-$ value atau $0.0027<0.05$.

9. Biaya Produksi $\left(\mathrm{X}_{4}\right)$ berpengaruh negatif dan signifikan terhadap Pendapatan (Y). Hal ini didasarkan pada nilai $\mathrm{t}_{\text {hitung }}>\mathrm{t}$ tabel yakni 2,282 > 1,677 maka tolak $\mathrm{H}_{4}$. Hal ini juga bisa dilihat dari probabilitas hitung $<\mathrm{p}-$ value atau $0.0272<0.05$.

10. Jumlah Produksi $\left(\mathrm{X}_{5}\right)$ tidak berpengaruh terhadap Pendapatan (Y). Hal ini didasarkan 
pada nilai $\mathrm{t}_{\text {hitung }}<\mathrm{t}$ tabel yakni 1,359 $<1,677$ maka tolak $\mathrm{H}_{5}$. Hal ini juga bisa dilihat dari probabilitas hitung < p - value atau $0.1808>$ 0.05 .

11. Secara simultan modal, luas lahan, pengalaman, biaya produksi dan jumlah produksi berpengaruh positif dan signifikan terhadap pendapatan (Y).

\section{Saran}

Adapun saran yang dapat diberikan peneliti dalam penelitian ini adalah sebagai berikut :

1. Bagi masyarakat, diharapkan untuk menggunakan area secara maksimal sehingga dapat meningkatkan hasil produksi.

2. Bagi peneliti selanjutnya, hasil penelitian ini dapat dijadikan sebagai bahan rujukan bagi peneliti selanjutnya.

3. Bagi petani sawah, diharapkan untuk meminimalkan biaya produksi yang digunakan sehingga mempunyai kesempatan bagi petani untuk mendapatkan pendapatan yang lebih besar.

4. Bagi petani sawah, diharapkan untuk mengelola kegiatan persawahan dengan lebih baik, sehingga dapat meningkatkan jumlah produksi yang lebih maksimal dan dapat menunjang kesejahteraan masyarakat.

\section{DAFTAR PUSTAKA}

Amirullah, Imam Hardjanto, (2005). Pengantar Bisnis, Edisi Pertama, Graha. Ilmu, Yogyakarta

Balai Penyuluhan Pertanian Kecamatan Samudera, 2018. Data Petani Sawah Kecamatan Samudera.

Boediono, (2000), Ekonomi Internasional, BFFE, Yogyakarta

BPS Aceh Utara, (2018). Aceh Utara Dalam Angka 2018. BPS Lhoksukon.

Cahyono. (2005). Budidaya Tanaman Sayuran. Penebar Swadaya. Jakarta.

Case dan Fair. (2007). Prinsip-Prinsip Ekonomi. Erlangga. Jakarta.

Choliq, Abdul, (2009), Pengantar Manajemen, Semarang: Rafi Sarana Perkasa
Damanik, J.A (2014). Analisis faktor-faktor Yang Mempengaruhi Pendapatan Petani Padi Di Kecamatan Masaran, Kabupaten Sragen. Economics Development Analysis Journal 3 (1) (2014). Universitas Negeri Semarang

Damihartini RS, Jahi A. (2005). Hubungan Karakteristik Petani dengan Kompetensi Agrobisnis pada Usaha Tani Sayuran di Kabupaten Kediri Jawa Timur, Jurnal Penyuluhan, Institut Pertanian Bogor. Volume 1, Nomor 1, September 2005: 43-48

Daniel, Moehar. (2002). Pengantar Ekonomi Pertanian. Jakarta: PT. Buni Aksara

Darwis, Valeriana. (2008). Keragaan Penguasaan Lahan Sebagai Faktor Utama Penentu Pendapatan Petani. Litbang Kementrian Pertanian RI. Jakarta.

Firdaus A.Dunia. (2013), Pengantar Akuntansi, Edisi 4. Jakarta: Fakultas Ekonomi. Universitas Indonesia.

Ghozali, Imam. (2007). Analisis Multivariate Dengan Program SPSS. Cetakan Empat. Badan. Penerbit Universitas diponegoro. Semarang.

Gujarati, Damodar.(2008). Dasar-Dasar Ekonometrika. Jakarta : Penerbit. Erlangga

Herjanto, Eddy, (2008), Manajemen Operasi Edisi Ketiga, Jakarta: Grasindo

Hernanto, F. (2001). Ilmu Usaha Tani. Jakarta: Penebar Swadaya

Husodo, Siswono Yudo. (2004). Pertanian mandiri Pustaka Pelajar,. Yogyakarta

Irawan dan M. Suparmoko. (2002). Ekonomi Pembangunan. Yogyakarta: BPFE

Irawan, et.al (2005). Pengendalian Konversi Lahan Pertanian: Tinjauan Ulang Kebijakan Lahan Pertanian Abadi. Proseding Seminar Nasional Multifungsi dan Konversi Lahan Pertanian. Bogor 2 
Oktober dan Jakarta 25 Oktober 2002. ISBN 979-9474-20-5:67-83

Jaya, A. H. M. (2011). Faktor-Faktor yang Mempengaruhi Pendapatan Pedagang Kaki Lima di Sekitar Pantai Losari Kota Makassar. Skripsi. Makassar: Jurusan Ilmu Ekonomi Feb Unhas

Joesron, Tati Suhartati dan Fathorrozi. (2003). Teori Ekonomi Mikro Dilengkapi. Beberapa Bentuk Fungsi Produksi. Jakarta: Salemba Empat.

Luntang, Purnomo (2012). Pengaruh Biaya Produksi, Lama Usaha, Produktivitas Terhadap Pendapatan Petani Salak Pondoh Di Desa Pronojiwo Kecamatan Pronojiwo Kabupaten Lumajang. eJournal Ekonomi Bisnis dan Akuntansi, 2018, Volume V (1) : 44-47. Ilmu Ekonomi dan Studi Pembangunan, Fakultas Ekonomi dan Bisnis, Universitas Jember (UNEJ)

Mawardati (2013), Analisis Faktor-Faktor Yang Mempengaruhi Pendapatan Usahatani Kentang Di Kabupaten Bener Meriah Provinsi Aceh. ojs.unimal.ac.id/index.php/agrium/article/v iew/494

Miller, R.L. dan Meiners E, R. (2000). Teori Mikroekonomi Intermediate, penerjemah Haris Munandar. PT. Raja Grafindo Persada, Jakarta

Mubyarto. (2003). Politik Pertanian dan Pembangunan Pedesaan. Jakarta Sinar Harapan.

Mulyadi. (2000). Akuntansi Biaya Edisi 5. Yogyakarta: Aditya Media.

Nugraha, Listyawan Ardi (2011). Pengaruh Modal Usaha, Tingkat Pendidikan, dan Sikap Kewirausahaan terhadap Pendapatan Usaha Pengusaha Industri Kerajinan Perak Di Desa Sodo Kecamatan Paliyan Kabupaten Gunung Kidul. Skripsi: Universitas Negeri Yogyakarta.

Partadiredja, Atje (2006). Pengantar Analisa Ekonomi Pertanian. Jakarta: Mutiara
Phahlevi (2013), Faktor-Faktor Yang Mempengaruhi Pendapatan Petani Padi Sawah Di Kota Padang Panjang. Vol 1, No 02 (2013). Jurnal Kajian Ekonomi dan Pembangunan. Universitas Negeri Padang.

Putong (2002), Pengantar Ekonomi Mikro dan Makro, Jakarta: Ghalia Indonesia

Priyatno (2010). Teknik Mudah dan Cepat Melakukan Analisis Data. Penelitian dengan SPSS dan Tanya Jawab Ujian Pendadaran. Gaya. Media, Yogyakarta.

Ridha (2017), Analisis Faktor-Faktor Yang Mempengaruhi Pendapatan Petani Di Kecamatan Nurussalam Aceh Timur. Error! Hyperlink reference not valid.

Saragih dan Saleh (2016), Faktor-faktor Yang Mempengaruhi Pendapatan Rumah Tangga Tani Padi (Studi Kasus: Desa Sei Buluh, Kec. Teluk Mengkudu, Kab. Deli Serdang). ojs.uma.ac.id/ index.php/ agrica/article/download/ 486/451

Salvatore, Dominick. (2001). Ekonomi Manajerial dalam Perekonomian Global. Salemba Empat: Jakarta

Samuelson. Paul \& William D Nordhaus. (2001). Mikro Ekonomi. Jakarta : Erlangga

Soekartawi, (2006). Agribisnis Teori dan Aplikasi. Rajawali Press

Sudarman, A. (2009). Teori Ekonomi Mikro BPFE, Yogyakarta.

Sugeng, (2003), Bercocok Tanamnan Padi,

Aneka Ilmu, Semarang

Suharsimi, Arikunto (2002). Metode Penelitian Suatu Praktik. Rosdakarya: Jakarta

Sugiyono (2003). Statistika Untuk Penelitian. Alfabeta: Bandung

Sukirno,Sadono, (2006), Ekonomi Pembangunan, Jakarta:Kencana

Sukirno, Sadono. (2004). Pengantar Teori Makroekonomi. Jakarta: PT Raja. Grafindo Persada. 
Sunuharyo, Bambang, (2007), Pendapatan dan Pengeluaran Rumah Tangga Pegawai Golongan Rendah. Rajawali Press, Jakarta.

Supriyono. (2004). Akuntansi Biaya Pengumpulan Biaya dan Penentuan Harga

Pokok, Buku 1 Edisi 2. Yogyakarta: BPFE

Sutarto. (2008). Dasar-dasar Organisasi. Yogyakarta: Gadjah Mada University Press.

Syafaruddin, (2003). Pengaruh Penyelenggaraan Penyuluhan Pertanian melalui Integrasi Dinamis antara Penyuluh Pertanian dan Petani. Jurnal Pasca Sarjana Pengelolaan Sumberdaya Alam dan Lingkungan

Swasta, Basu dan Ibnu Sukotjo, (2008), Pengantar Bisnis Modern, Cetakan. Ketiga, Liberty, Yogyakarta.

Umar, H. (2009). Metode Riset Perilaku Konsumen Jasa. Jakarta: Ghalia Indonesia.

Winarno (2007). Analisis Ekonometrika dan Statistik dengan Eviews. Yogyakarta.UPP STIM YKPN. 